given by his formula, but as the formula is clearly inaccurate for temperatures above $10^{\circ} \mathrm{C}$. it is premature to conclude, as he does, that the surface water is supersaturated with oxygen.

J. Y. BUCHANAN

(To be continued.)

\section{THE BOSTON SOCIETY OF NATURAL} HISTORY, I830-1880

\section{$\mathrm{T}$}

HE Boston Society of Natural History was founded in 1830 by a few earnest men, and in 1880 it resolved to commernorate its fiftieth anniversary by the publication of an historical sketch of its origin and life, and of a special series of scientific memoirs. This resolution has been carried into effect by the issue of a splendid quarto volume of over 600 pages and 40 plates, the paper and typography of which is worthy of the Boston Press.

Very interesting is the account given of the early struggles and early successes of this now so well-known institution. Preceded by the Linnean Society of Boston (founded in 1814), which at first made rapid progress and then gradually fell away, it was duly constituted in May, I830, with Thomas Nuttall as president. At this time, Mr. S. H. Scudder states, there was not in New England an institution devoted to the study of natural history; there was not a college, except Yale, where even the modern views of geology were taught. The few labourers in the field of natural science worked alone, without aid or encouragement, and were regarded as triflers by a busy public. To go through the records of its early days, however briefly, would take up too much of the space at our disposal.

Once started into existence, the Society found itself with the responsibility of a rapidly increasing museum; and the demands upon its pecuniary resources, even though an enormous amount of gratuitous service was rendered by the members, soon began to be very troublesome. Generous and wealthy members replenished the empty treasury, and after its first ten years' existence (I830-40) it found itself, after a hard pinch, just free from debt. In $184 \mathrm{I}$ the publication of the Fournal of the proceedings commenced. Louis Agassiz joined the Society in 1847. Dr. Amos Burney, its president, died the same year at Rome. In 1848 the members assembled in a new house in Mason Street, and the close of a second decade (I840-1850) found them just holding their own.

Already in 1855 it became evident that the new abode was becoming all too small for the collections; and now it was well for the Society that they found so good a friend in John C. Warren, for he largely assisted in procuring the means for purchasing the present accommodation, though another ten years (1850-60) passed away, and it was not until I86I that Dr. William J. Walker presented the Society with the estate in Bulfinch Street, where the Society's fine museum and library now stands. The magnificent donation of 10,000 dollars from Mr. Jonathan Philips, the products of the sale of the house in Mason Street, with many generous subscriptions, enabled the Society to think of building on the site presented to them by Dr. Walker, but on consideration they found that they had not more than half the money amount required. In this emergency Dr. Walker came again to their aid, presenting them with a gift of 20,000 dollars, on condition that a further sum of like amount were raised. The year I 864 found the Society in its present handsome edifice (the building of which had cost 80,000 dollars) and trying to solve the problem of how to keep up so spacious a mansion on its comparatively small resources. With wondrous liberality Dr. Walker once more offered a donation of 20,000 dollars, on the condition that a like amount were subscribed by others, the whole to form a working capital to be funded. This became an accomplished fact in Mav, I 864, but this was not all, for on Dr. Walker's death in April, 1865 , it was found that he had left by will a large fortune to the Society, and following this good example ere this fourth (1860-70) decade passed away, other liberal members had subscribed some 50,000 dollars to the capital of the Society, thus establishing the Institution on such a firm foundation as to secure its perpetuity as long as wisdom shall prevail in its Councils. Its property, besides the buildings with their inestimable contents, consisted of vested funds, amounting to $186,898 \cdot 20$ dollars, and a fair annual income from members.

The fifth decade, the celebrating of the close of which too's place in April, 1880, was chiefly noted for the progress that was made in a scientific arrangement of the collections of the Society, under the custodianship of Mr. Hyatt; by the deaths (I874) of Louis Agassiz, about whose early career some very interesting facts are given, and (1874) of Jeffries Wyman, of whom there is a short biography, of Charles Pickering 1878), of C. F. Hartt (1868), and of T. M. Brewer (1880).

There is a very valuable account of the Teachers' School of Science, which seems in Boston to have attained a great success, and a summary of the general contents of the Museum. Very excellent portraits of Benjamin D. Greene, George B. Emerson, Amos Binney, J. C. Warren, Jeffries Wyman, and Thomas T. Bouvé, being the first six presidents of the Society, accompany this part of the volume and also a history of Dr. William J. Walker, and engravings of the portraits of A. A. Gould and Dr. Humphreys Storer.

The second portion of this fine memorial volume is devoted to the publication and illustration of a series of memoirs, of which we must be content with the bare enumeration of their titles. These are thirteen in number, and are profusely illustrated : N. S. Shaler, Propositions concerning the Classification of Lavas considered with Reference to the circumstances of their Extrusion; A. Hyatt, the Genesis and Evolution of the Species of Planorbis at Steinheim (ten plates and a map); S. H. Scudder, the Devonian Insects of New Brunswick, with a Note on the Geological Relations of the Fossil Insects from the Devonian of New Brunswick, by Dr. J. W. Dawson (one plate) ; W. G. Farlow, on the Gymnosporangia (Cedar Apples) of the United States (two plates); Theodore Lyman, on a New Structural Feature, hitherto unknown among Echinodermata, found in Deep Sea Ophiurans (two plates); W. K. Brooks, the Development of the Squid (Loligo pealii, Les.), three plites; A. S. Packard, jun., the Anatomy, Histology, and Embryology, of Limulus polyphemus (seven plates); Edward Burgess, Contributions to the Anatomy of Danais archippus, Fab. (two plates); Saml. F. Clarke, the Development of a Double-Headed Vertebrate (one plate); C.S. Minot, Studies on the Tongues of Birds and Reptiles (one plate) ; Edward S. Morse, on the Identity of the Ascending Process of the Astragalus in Birds with the Intermedium (one plate); Lucien Carr, on the Crania of New England Indians (two plates); William James, the Feeling of Effort.

\section{THE PHYSIOGNOMY OF CONSUMPTION ${ }^{1}$}

$T H E$ idea that a certain type of face indicates a tendency to certain diseases is not only widely diffused in the medical profession, but among the public at large, as is shown by the frequent occurrence of such phrases as "consumptive-lookin " and "apoplectic-looking." With a view to ascertaining how far these generally-entertained ideas are true, and of substituting for mere personal impressions the test of exact and unprejudiced investigation, the authors of this paper have made a number of observations by the method of composite portraiture, already described by Mr. Galton in NATURE. The countenance which is supposed to indicate a tendency to phthisis or

$$
\text { "An Inquiry into the Physiognomy of Phthisis, by the Method of }
$$
Composite Portraiture." By Francis Galton, F.R.S., and F. A. Mahomed, M.D. 